\title{
Dendrochronology in Latin America, state of the art and contributions for understanding climate variation
}

\author{
Oscar D. Sánchez ${ }^{1}$, Manuel E. Mendoza ${ }^{1 *}$, Teodoro Carlón-Allende ${ }^{2}$ and José Villanueva Díaz ${ }^{3}$ \\ 1 Centro de Investigaciones en Geografía Ambiental, Universidad Nacional Autónoma de México, \\ Antigua carretera a Pátzcuaro No. 8701, Colonia Ex - Hacienda de San José de la huerta. CP \\ 58190. Morelia, Michoacán, México; e-mail: ocalderon@pmip.unam.mx; mmendo- \\ za@ciga.unam.mx \\ 2 CONACYT-Instituto de Geofísica, Unidad Michoacán, Universidad Nacional Autónoma de México, An- \\ tigua Carretera a Pátzcuaro No. 8701 Col. Ex-Hacienda de San José de La Huerta C.P. 58190, Morelia, \\ Michoacán, México; e-mail: tcarlon@igeofisica.unam.mx \\ 3 Instituto Nacional de Investigaciones Forestales, Agrícolas y Pecuarias, Centro Nacional de Investigación \\ Disciplinaria en la Relación Agua - Suelo - Planta - Atmosfera, Laboratorio de Dendrocronología Km 6.5 \\ Margen derecha del canal de Sacramento, C.P. 35140. Gómez Palacio, Durango, México; e - mail: villa- \\ nueva.jose@inifap.gob.mx \\ * Correspondence: mmendoza@ciga.unam.mx
}

\begin{abstract}
Dendroclimatology has gained relevance during the XXI century. We analyze the state of-the-art of dendroclimatology in Latin America during the past 28 years (1990 to 2019), identifying the current state and recent advances in the application of dendroclimatology in this region. We carried out a systematic review in ScienceDirect, Web of Science, and Scopus databases using Boolean operators to logically connect the keywords "dendrochronology," "dendroclimatology," "trend," "climatic variability," and "climatic variability trend", for each country. Dendroclimatological research conducted in the region focused on climatic reconstruction and the evaluation of new tree species with dendrochronological potential, which increase in 2010, then there was a gap between 1995 and 1996, later increase to present. Dendroclimatological studies in Latin America have been mainly developed in temperate climate zones $(82.4 \%)$ followed by tropical or subtropical areas $(17.6 \%)$. Dendroclimatological research in Latin America has provided advances in the study of climate variability by defining response functions of tree rings to climate. The generated information allows for a better understanding of the spatial and temporal dynamics of climatic variability and about its effects on ecosystems and society. We also call for increased dendroclimatological research based on subtropical and tropical forests limited studied until today.
\end{abstract}

Keywords: Latin America, tree ring analyses, dendrochronology, climatic trends, climate variability, review.

\section{Introduction}

Dendroclimatology, as a discipline, surges by the integration of climatology and dendrochronology during the first quarter if the last century [1]; nevertheless, dendroclimatological studies in Latin America are relatively recent, especially when 
compared to the pioneering work carried out in beginning of the twentieth century $[1,2]$; These studies have considerable importance in this geographic region due to its broadly distributed and diverse ecosystems in its territory [3]. The aim of dendroclimatology is to study the historical fluctuations of climate based on the variation of ring widths in a time interval, considering them as a historical-biological archive in which climatic variability is recorded through the activity of the vascular cambium [2,4].

The first dendroclimatological research in South America was also performed by Schulman (1956) in Chile and Argentina, in which the first chronologies were developed for Austrocedrus chilensis, a species he found to be sensitive to a lack of humidity $[5,6]$. Over the past 30 years, dendroclimatological studies have been extensively developed in northern Mexico, the Andes, the Bolivian Plateau, the Chaco and Pampa, the Amazon forest, Cerrado and the Atlantic rain forest regions, as well as in Patagonia [5,7-13].

A few reviews have been published about scientific advances of dendrochronological studies in Latin America (Mexico and South America) that deal with climatic reconstructions, the influence of ocean-atmospheric phenomena on climate variability, and species with dendrochronological potential in temperate, subtropical and tropical environments $[4,5,7,14]$, as well as the application of dendrochronology for the sustainable management of commercial timber species and the increase of available paleoclimatic information [15,16]. In the last decade, however, no literature review specifically about current knowledge in dendroclimatology and climate variability in Latin America has been done, which is important when considering the influence of atmospheric circulatory models on biomass production, carbon sequestration, and other environmental services useful in developing strategies for a sustainable ecosystem management $[5,17]$. Thus, in the present work, we focus on analyzing papers published in journals included in the Journal Citation Reports (JCR) with the objective of analyzing the state of-the-art of dendroclimatology and climate variability in Latin America for the past 29 years (1990 to 2019).

\section{Materials and methods}

We surveyed the recent papers through digital libraries in the ScienceDirect, Web of Science, and Scopus databases using the key words "dendroclimatology," "dendrochronology," "trend," "climatic variability," and "climatic variability trend" by each Latin American country. The main constraints for this research were as follows: 1) the selection of publications dealing with dendroclimatology, 2) the selection of case studies from Latin America, and 3) the exclusion of manuals, theses, informatic tools, and conference proceedings. The gathering and systematization of the information were made by applying a quantitative process that increased search efficiency.

The search was applied by means of Boolean operators establishing the following connections: "Dendroclimatology and Climatic Variability Trend", "Dendrocronology and Climatic Variability Trend", "Dendrochronology" by each Latin American country and "Dendroclimatology", by each Latin American country. With the objective of establishing two sets of queries and of simplifying the management of the information, the described choices were summarized into two main groups: "dendrochronology and 
Latin America" and "dendroclimatology and Latin America." The resulting database was filtered by the abovementioned criteria focused on dendroclimatology in order to depurate the list of selected papers.

To systematize the information, the selected articles resulting from queries in the databases were organized according to the assessment of their content (Table 1). During the systematization and analysis stage, a standardized database was created and divided into five main sections: 1) general data, 2) study area, 3) research objectives, 4) methodological developments, and 5) the relationship between climatic variability and dendrochronology.

Table 1. General description of the data required for the evaluation of the content of papers regarding the study of dendroclimatology

\begin{tabular}{|c|c|c|}
\hline Concept & Variable & Description \\
\hline \multirow[t]{10}{*}{ General information } & \multicolumn{2}{|l|}{ Who and When? } \\
\hline & Author & Who wrote the paper? \\
\hline & Year & In which year was it published? \\
\hline & Title & Which is the title of the paper? \\
\hline & \multicolumn{2}{|l|}{ Where? } \\
\hline & Journal name & In which journal was it published? \\
\hline & Volume & In which volume was it published? \\
\hline & Number & In which number was it published? \\
\hline & Institution or publisher & To which institution or publisher does the journal belong? \\
\hline & Country of publication & Which country is the journal from? \\
\hline \multirow[t]{3}{*}{ Study area } & Country & In which country was the work made? \\
\hline & Location & Where were samples gathered? \\
\hline & Surface of study & What surface did the study cover? \\
\hline \multirow{6}{*}{$\begin{array}{l}\text { Objective } \\
\text { research }\end{array}$} & \multicolumn{2}{|l|}{ Why and for what? } \\
\hline & $\begin{array}{l}\text { Number of samples } \\
\text { collected }\end{array}$ & How many samples were collected to make the study? \\
\hline & Sampled species & $\begin{array}{l}\text { Which are the more common species for dendroclimatological } \\
\text { studies? }\end{array}$ \\
\hline & $\begin{array}{l}\text { Relation of } \\
\text { dendroclimatology to other } \\
\text { sciences }\end{array}$ & $\begin{array}{l}\text { Which papers are related to other sciences? How are the } \\
\text { tools of dendroclimatology assimilated? How does } \\
\text { dendroclimatology adopt analytical techniques from other } \\
\text { disciplines? }\end{array}$ \\
\hline & $\begin{array}{l}\text { Effects of climatic } \\
\text { variability on the growth of } \\
\text { trees }\end{array}$ & $\begin{array}{l}\text { Which papers have as an objective to analyze the effects of } \\
\text { climate on growth and the population dynamics of forest } \\
\text { stands? }\end{array}$ \\
\hline & Climatic reconstruction & $\begin{array}{l}\text { Which papers have climatic reconstruction as their main } \\
\text { objective? }\end{array}$ \\
\hline
\end{tabular}




\begin{tabular}{|l|l|l|}
\hline \multirow{3}{*}{ Methodology } & \multicolumn{2}{|l|}{ How? } \\
\cline { 2 - 3 } & Design of data sampling & $\begin{array}{l}\text { Which papers propose dendrochronological sampling } \\
\text { methods? }\end{array}$ \\
\cline { 2 - 3 } & $\begin{array}{l}\text { Search for new species for } \\
\text { dendroclimatology }\end{array}$ & $\begin{array}{l}\text { Which articles look for new species that can help to better } \\
\text { understand the interannual and multiannual climate } \\
\text { variability? }\end{array}$ \\
\cline { 2 - 3 } & $\begin{array}{l}\text { Application of alternative } \\
\text { or parallel dating methods }\end{array}$ & $\begin{array}{l}\text { Are there papers in which alternative methods of dating or } \\
\text { climate analysis are applied? }\end{array}$ \\
\hline $\begin{array}{l}\text { Relation of basic } \\
\text { concepts }\end{array}$ & \multicolumn{2}{|c|}{ How? } \\
\hline $\begin{array}{l}\text { Relation of climatic } \\
\text { variation with } \\
\text { dendrochronology }\end{array}$ & $\begin{array}{l}\text { Dendrochronological data } \\
\text { for establishing associations } \\
\text { with climatic variables }\end{array}$ & $\begin{array}{l}\text { Which papers posed the specific goal of considering series of } \\
\text { dendrochronological indexes to establish a correlation with } \\
\text { meteorological stations? }\end{array}$ \\
\hline
\end{tabular}

After, a list was made of the articles resulting from the application of the first selection filter for each database (ScienceDirect, Web of Science and Scopus) we compared each database to identify duplicate articles and articles found in two or more of these datasets. The articles found in two or more datasets were purged leaving a single version of the repeated titles. Finally, a list was made considering the articles that were not duplicated in the databases and a single version of the articles that were repeated in two or more databases.

To observe the annual trend of publications, the nonparametric Mann-Kendall trend test was applied, which provided a qualitative observation parameter to determine a potential trend [18] in the number of annual publications.

\section{Results}

The three consulted databases produced similar outputs for searching articles. For instance, in ScienceDirect, Web of Science and Scopus, the query based on the terms "dendrochronology" produced 2,201, 2,189, and 2,289 articles, respectively. The search using the keyword "dendroclimatology" produced 542, 785 and 653 papers in ScienceDirect, Web of Science, and Scopus, respectively. Although using a combing of keywords (Dendrochronology and Trend, Dendroclimatology and Trend, Dendrochronology and Climatic Variability, Dendroclimatology and Climatic Variability) always produced a higher number of articles in ScienceDirect in comparison to Web of Science and Scopus databases (Figure 1), while, the last two databases produced a similar number of articles using the same combination of keywords. 

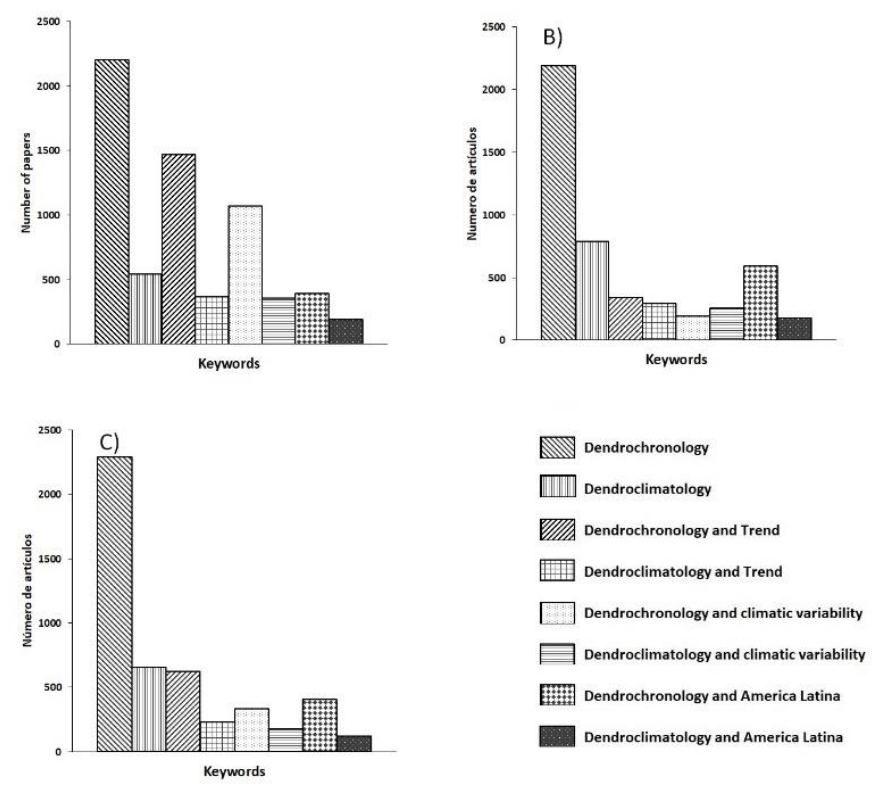

Figure 1. Publications about dendroclimatology in Latin America between the years 1990 and 2019.

3.1. Which is the publication trend and where is published the dendroclimatic research in Latin America?

The number of publications about dendroclimatology in Latin America has increased during the study period. Such a rise displayed two patterns: one with fewer than 5 publications per year between 1990 and 2004 and the second one with more than 10 publications per year between 2005 and 2018, where a peak of 20 publications in a year was reached in 2016 (Fig. 2). Nevertheless, the results from the Mann-Kendall test did not depicted a significant trend $(\mathrm{Z}=0.60)$.

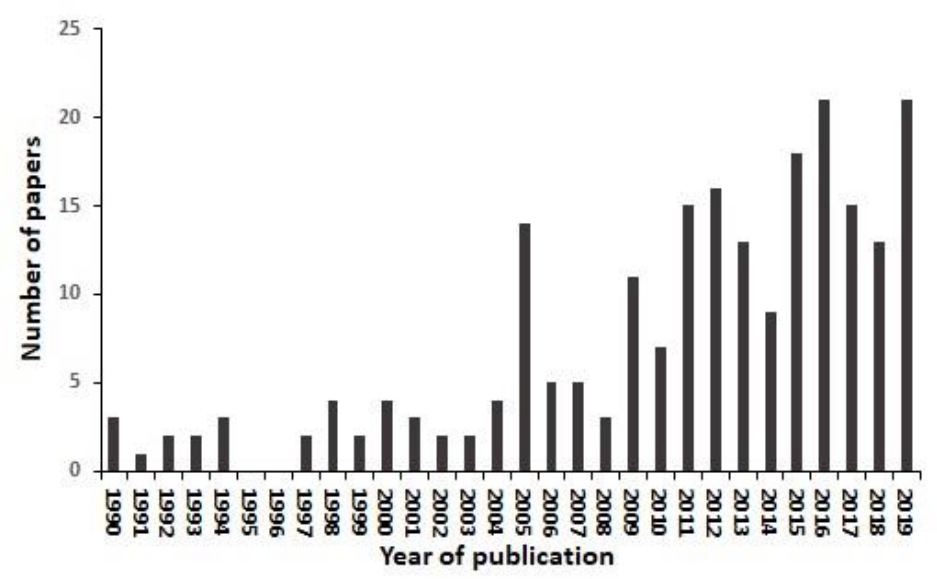

Figure 2. Quantification of papers related to the key words searched for in the ScienceDirect (A), Web of Science (B), and Scopus (C) databases.

The main authors in the region are based on Argentina, Chile, the United States of America, and Mexico. Regarding the nationality of the editorial offices, the selected 
papers were published in international journals (68), German journals (23), Journals of the United States of America (19), Mexican journals (19), Italian journals (12), Holland (10) and Chile (10), rest of the editorial offices by country published less than seven articles (Figure 3). We considered journals as international when they had offices or editorial representation in different countries.

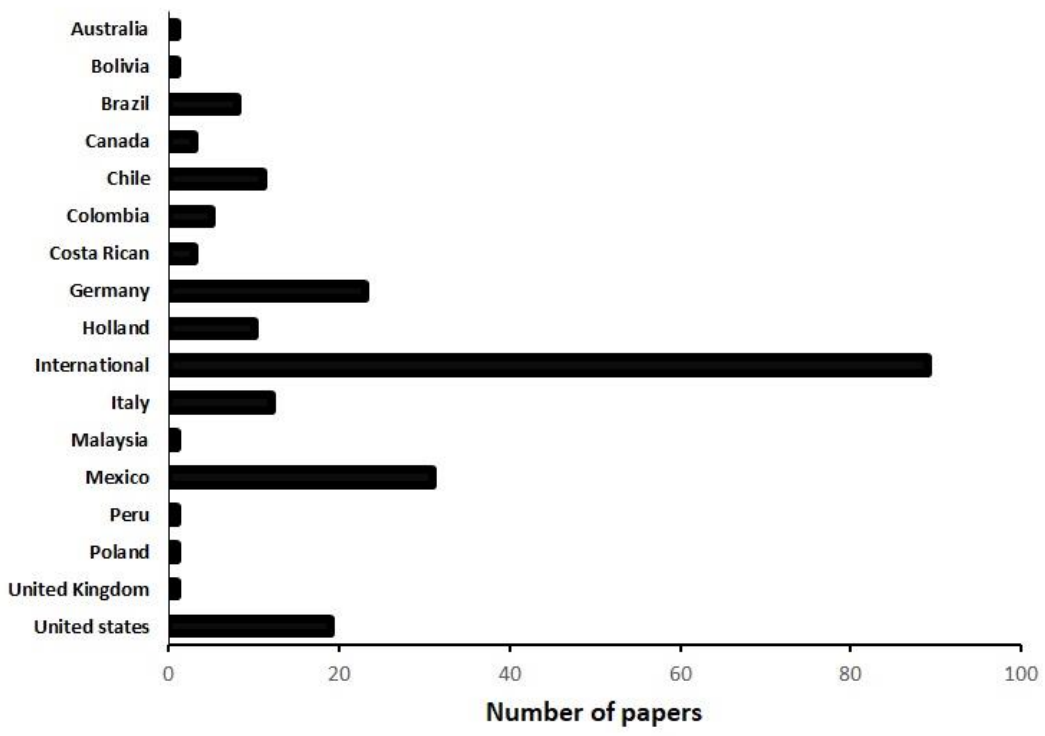

Figure 3. Nationality of journals in which papers

From a total of 220 publications conducted in Latin America, between 1990 and 2019, 31\% (67 papers) were published by Elsevier, 14 \% (30) by Springer, and $7 \%$ (16) by WIREs. The remaining publishers belonging to several universities and scientific societies published a total of 107 papers, averaging 2 papers per publisher (Figure 4). 


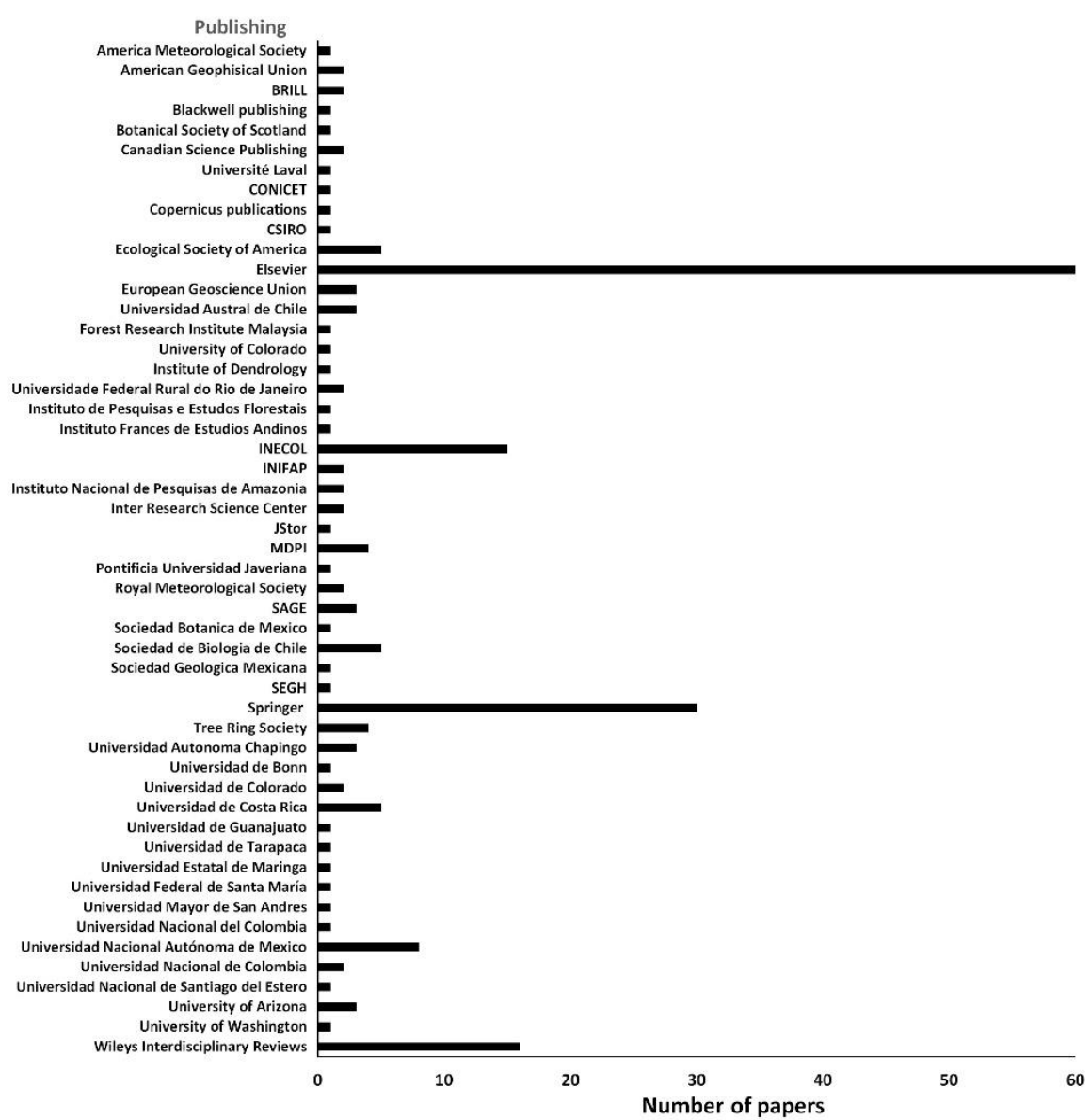

Figure 4. Number of articles published by publisher.

\subsection{Which are the study scales in dendroclimatological research?}

Of the 220 papers, 102 (46\%) studies were developed at the local level and 118 (54\%) at the regional level. Of the published research having local scale goals, 57 papers indicated the effects on tree growth of climatic variability, 33 referenced the interaction of dendroclimatology with other sciences, and 12 referred to the reconstruction of past climate. Among the 118 published studies performed with a regional scope, 20 mentioned contributions of dendroclimatology as an auxiliary science for specific objectives, 53 referred to the analysis of climatic variability and tree growth, and 45 had the objective of reconstructing climate. Regional studies are related to the study of atmospheric phenomena or climatic variability while local studies are associated with the glacial thaw, searching for new dendroclimatic species for analysis and dendroclimatic response at different topographic positions.

3.3 Where dendroclimatological research is generated?

Among countries that develop dendroclimatological studies, Mexico (84), Argentina (57), and Chile (33) were more active in publishing, followed by Brazil (28), Bolivia (8), Costa Rica (2), Guatemala (2), and Colombia (6); that means regionally, South America was dominant in the discipline.

Dendroclimatological studies in Latin America have been mainly developed in temperate climate $(65 \%)$ zones and a lower percentage in tropical or subtropical areas 
(35\%). In terms of research institutions involved in Dendroclimatological issues, those located in South and North America were half nearly with $49 \%$ of the total publications. The prominent research institutes were the Argentinian Institute of Snow and Glacier Research and Environmental Sciences (IANIGLA by its Spanish acronym) and the National Scientific and Technical Research Council of Argentina (CONICET by its Spanish acronym). The IANIGLA participated in $26 \%$ of the dendrochronological research in Latin America. Furthermore, in Chile the IANIGLA promoted 32\% of the published articles, followed by the Universidad Austral de Chile with $24 \%$. In Peru, the IANIGLA produced $29 \%$ of the articles published, and other institutions were in second place with 71\%, such as the Universidad de Antofagasta, the Universidad de Piura and the Universidad Nacional de Colombia. In Brazil, the Universidad de Sao Paulo and Universidad Federal de Sergipe developed 36\% of the articles produced; the research in Brazil is mainly performed by universities and research institutes, making up $13.2 \%$ of the dendroclimatic research in Latin America. In Mexico, the National Institute for Forestry, Agricultural and Livestock Research (INIFAP by its Spanish acronym) conducted $14.0 \%$ of the studies on dendroclimatology, the Universidad Nacional Autónoma de México (UNAM by its Spanish acronym) participated with $18.6 \%$, and the Universidad Juárez of the State of Durango (UJED) performed 15.1\%. Of the studies made in Mexico, 57.0\% were developed by public educational institutions and research centers. Universities from the United States of America also had a significant contribution, such as the Northern Arizona University $(9.3 \%)$, the University of Arkansas (8.1 \%), and the University of Arizona (4.7\%). Latin American dendroclimatologist are the principal writers in Latin America, published papers have an average three authors (20\%).

Regarding regions, researched sites in South America were mostly concentrated in the Andes of Argentina, Bolivia, Chile, and Peru, and to a lesser extent in Colombia and Ecuador. In Argentina and Chile, the regions with more dendroclimatological studies were the Pampa, Patagonia, Chaco, Arica, Parinacota and Valdivia; nineteen works were developed in the Amazon region and the Atlantic coast of Brazil. Only five research sites were reported in Central America, three of which mention the nearest localities: Monteverde and Guanacaste in Costa Rica and the Sierra de los Cuchumatanes in Guatemala. A high percent of the research developed in Mexico occurred in the northern part of the country, mostly in the Sierra Madre Occidental and the Sierra Madre Oriental, with a lower percent in central and western Mexico within the Trans-Mexican Volcanic Belt. Only one study was reported for the Yucatán Peninsula in southern Mexico (Figure 5). Most of the studies have been developed for reconstructing precipitation and evaluating the sensitiveness of the species to precipitation, followed by the sensitivity to temperature. 


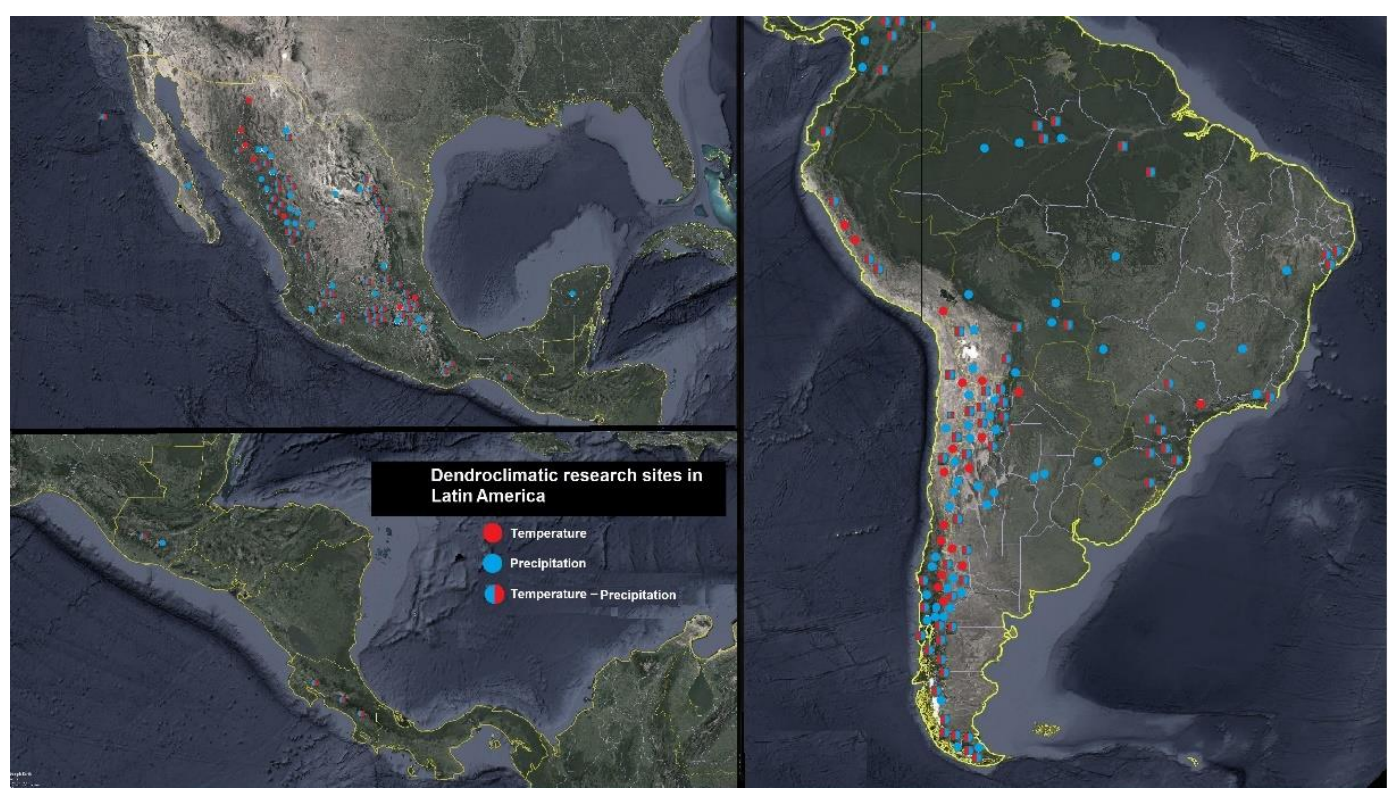

Figure 5. Location of sites of dendroclimatological research in Latin America.

Other spatial information included in this work was the extension of the studied areas, but only three papers (Costa Rica, Mexico, and Brazil) explicitly provided that information. The most studied biome for dendroclimatological studies is the temperate forest; semidesert biome is in second place, and the rain forest occupied the third place. The temperate forest is one of the most studied ecosystems given that the species there produce reliable annual rings sensitive to climatic factors.

3.5 Why and for what is dendroclimatic research made in Latin America?

3.5.1 Sampling and species collected

Dendroclimatic studies are usually carried out by analyzing several types of wood samples. Out of the total published scientific studies, $44.0 \%$ used increment-cores, $4.0 \%$ increment-cores and cross sections, $14.0 \%$ cross sections, $3.0 \%$ used available tree-ring series from international databases, and $35.0 \%$ did not mention the sampling type used. The highest sample size in dendrochronological studies consisted of 1477 increment-cores, while others had 1159, 1082 and 916 core samples [19-21]. Furthermore, the lowest number of samples was 4 cross-sections [22], with the average being 175 samples per study (Figure 6). Nevertheless, most of the papers omitted to mention the size of the sampled area, therefore, it became difficult to extrapolate the number of samples per unit area and the number of replicates. Some of these papers provide information about the number of sampled trees, the number of cores per tree, and the period in which the expressed Population Signal (EPS) was higher than 0.85. This information has been considered crucial for all statistical analyzes and a threshold value in dendrochronological research. 


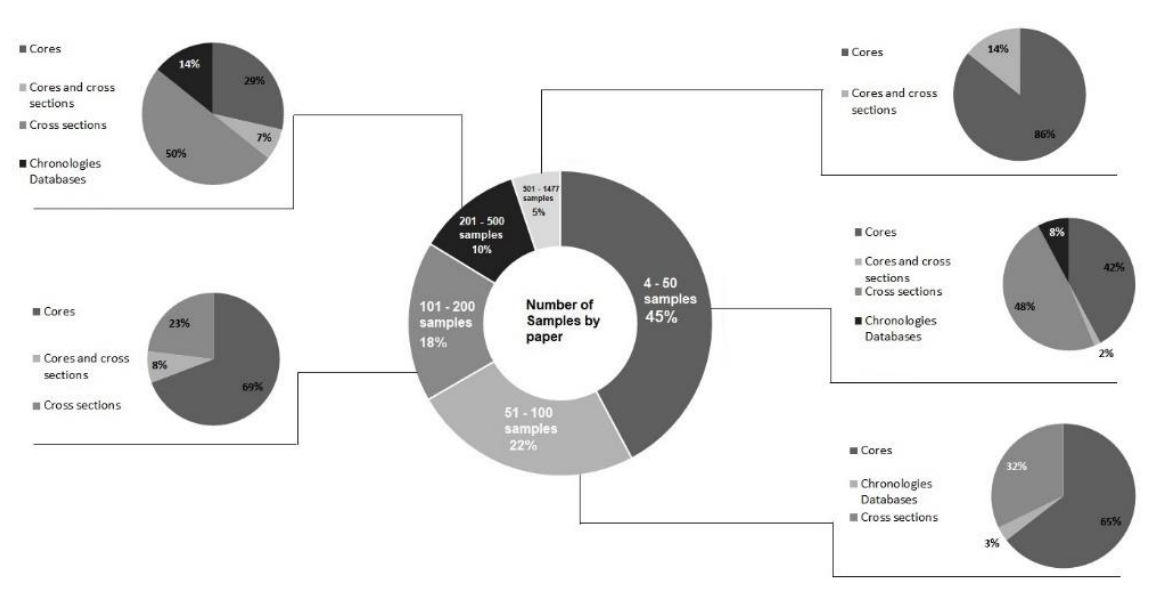

Figure 6. Type and number of samples used in dendroclimatology in Latin America.

Dendroclimatological research in Latin America has provided important advances in the study of historical climate variability by defining response functions. The angiosperm group in which broadleaf tree species follow conifers in dendrochronological work is of great importance, and some papers include up to seven different species. Some studies involving broadleaf species focused on exploring their potential for climate sensitivity, mostly in tropical, subtropical, and semiarid environments [23,24]. Conifers are more used for this kind of studies, because they produce well defined annual rings, their species diversity, wide distribution range, and longevity. The common climatic response detected throughout larger areas allows their integration into studies of regional climate variability and the analysis of the influence of ocean-atmospheric circulation modes [25-27].

In terms of highly sensitive species for dendroclimatic studies, the genus Pseudotsuga and Austrocedrus are preferred. The latter genus is characterized by producing anatomically well-defined rings and by being sensitive to changes in humidity [20,28,29]. The genus Pseudotsuga is a very climatically sensitive species and mostly responds to the seasonal winter-spring precipitation in northern Mexico and Southwestern United States. Its well-defined annual rings and wide distribution in one of the most extensive arid regions of North America have also been used for their suitability in dendrochronological studies [30-34].

Overall, conifers have been included in $64.0 \%$ of the dendrochronological papers published in Latin America, while broadleaf trees represented $46.0 \%$ of the published papers in this discipline --a high percentage of which grow in temperate areas and only $18.0 \%$ in dry or tropical climates--. An article about the genus Fitzroya was first published in 1990 regarding conifers, which later increased the interest in other genders like Pseudotsuga (2002), Pinus (2000), and Abies (1991) in Latin America. On the other hand, the number of published articles increased around 2005, and later in 2007 the first article in Taxodium was published, denoting the importance of this gender in dendroclimatology. The publication of broadleaf gender studies started with Nothofagus and continued with Juglans and Cedrela in 1989 and 1990. In 2004 and 2005, the number 
of publications about those genders increased. Another important broadleaf gender is Prosopis; the first study was carried out in 2004, followed by a second one in 2016. Other important genders of broadleaf are Fraxinus, Podocarpus, Schinopsis and Macrolobium, which began to be studied in 2010 (Figure 5).

\subsubsection{Relation of dendroclimatology to other sciences}

Of the 220 papers analyzed, in 165 of them we identified a relationship with other scientific disciplines. This relationship is based on the association of dendrochronological series with climatic or hydrological records to achieve specific objectives. Examples of such relationships are with hydrology in cases in which gauge records of streamflow, the water yield at upper watersheds, and extreme flood events are used for streamflow reconstructions. Additional studies reported that tree rings are related to dendrochemistry involving heavy metal concentrations from several pollutant sources and isotopic compositions like carbon-14, as affected by the burning of fossil fuels $[33,35,36]$. Other studies have been focused on the influence of climatic factors on growth rates and forest biomass production to establish growth models for forecasting commercial biomass volumes in native forests [37]. Additional dendroclimatological studies deal with the use of dendrochronology in climate warming by analyzing the decrease in precipitation and the rise in temperatures regarding glaciers' stability [20]. The use of dendrochronology to analyze patterns of insect outbreaks in years with droughts and higher temperatures has been an important issue in the last decades [38-40].

We identified 16 papers in which dendroclimatic analysis was applied to determine the historical recurrence of forests fires, to assess the evapotranspiration rates from tree species, and to estimate water balances [41-43]. The nature of the latter analyses, however, sometimes makes it necessary to use other parallel chronological dating methods in order to broaden the time scale of observations and to obtain higher precision in dating, such as carbon-14, decay of oxygen-18 (180) isotope, lichenometry, or geological stratigraphy [35,36]. The main objective of these papers is to determine the samples age that are inadequately observed, to relate the decay of the abovementioned isotopes with atmospheric phenomena, to study atmospheric contamination issues derived from burning of fossil fuels and its relationship with global warming, and the calibration of dating methods [36,44].

3.5.3 Effects of climatic variability on the growth of trees and reconstruction of past climate

The percentage of studies referencing the effects of climatic variability on growth dynamics is the highest found in our review with 110 papers (50\%). In Mexico, such analyses were mainly made regarding conifer species (Pinus, Pseudotsuga, and Abies) and have enhanced the understanding of the growth dynamics of forest mass in relation to climatic events like droughts, rainfall variability, and the impact of atmospheric circulatory models [45-49]. Similarly, other genera, i.e., Araucaria, Prosopis, Austrocedrus, Bursera, Macrolobium, Hymenaea and Podocarpus, have also been used for analyzing climatic phenomena in South America [29,38,50-53]. 
The reconstruction of past climates is the second most important topic with 57 publications; however, this is difficult to analyze because of the stringency of the tests applied to the data for observing the signal of climatic sensitivity, the low sample depth, and the short-time period covered by dendrochronological series, all of which increase the percentage of error [6]. The climatic signal makes it easier to observe climatic effects and to correlate annual radial increase and forest growth with meteorological variables, as well as to apply techniques like data cross-referencing, which allows determining patterns and their spatial distribution [54].

\subsection{How is dendroclimatic research performed in Latin America?}

3.6.1 Searching suitable species for dendrochronology

The assessment of the suitability of tree species for dendrochronological purposes was the main objective in 83 papers, of which $45.8 \%$ referred to species from temperate climates, and $44.6 \%$ studied dry or tropical tree species. In the early 1990s, the search for suitable species for dendrochronology began, mostly among conifers and broadleaf tree species from South America. For temperate climates, 23 papers report a particular species for the first time, while for the dry and tropical climates we also found 25 papers with that purpose. A main contrast was found in the number of species reported that aimed at assessing the species' suitability for study in different climates, which were 19 species per paper in temperate climates and 83 species per paper in dry and temperate climates. During that period, also in North and Central America, studies were made of other broadleaf and conifer species and were mainly focused on extrapolating dendroclimatological information to other areas where the same species are relatively abundant. Publications reporting the search for the suitability of studying new species followed an increasing trend, and between 2000 and 2010 this search was considerably broadened. In these papers, it is characteristic that several species or even several families were included, mostly using a minimum of 2 species and in one case over 50 species of broadleaf trees from dry climates. Mostly among species from arid and subtropical climates, such as Prosopis ferox, Prosopis flexuosa and a wide variety of other broadleaf tree species, they were frequently studied before 2010, but the trend stabilized thereafter.

\subsection{How is climatic variability related to dendroclimatology?}

In $69.0 \%$ of the papers, the methodological approach was based on establishing a significant association between climatological data and dendrochronological time series. This technique can be considered a link between dendrochronology and climatology, such that this is the most frequently applied technique in this field of knowledge. The first step consists of accurately dating the growth rings and verifying the precision by a statistical procedure; the next step implies the removal of the biological and geometrical trends in growth, which appears in a normalized dendrochronological series. This process requires a previous analysis starting from the verification of the quality of the climatic response. In this analysis, principal component analysis can be applied between climatic data and tree-ring series. The analysis allows selecting a group of chronologies with a similar climatic response indicated by the greater variance and to use the reduced chronologies to compare to climatic data. The relationship can also be obtained by a 
Pearson correlation or a multiple correlation analysis, allowing the production of a reconstruction model that must be calibrated and verified before being used for reconstruction purposes [32,55,56]. One of the most important objectives of dendroclimatological studies is to integrate a dendrochronological network of tree-ring series to analyze the climatic response at the regional or national scale and to determine the significant influence of atmospheric circulatory phenomena. In that regard, the Mexican Drought Atlas (MXDA) provides an estimation of dominant drought conditions based on the Palmer Drought Severity Index for June through August between 1400 and $2012[57,58]$.

\section{Discussion}

Our search of published scientific information about the topics of dendrochronology and dendroclimatology showed differences between the higher number of papers in ScienceDirect relative to those in the Scopus and Web of Science databases in searches of the key words "dendrochronology and trend," "dendroclimatology and trend," and "dendrochronology and climatic variability." Such differences may have been due to the number of journals subscribed to each database, their geographic areas of influence, and the degree of specialization regarding our topics of interest. The relationship between key words and the application of Boolean operators allowed us to find research spaces within dendroclimatology related to the topic "trends of climatic variability."

The estimation of trends in climatic variability has not been undertaken, probably due to the complexity implied in the process of climate reconstruction [35] based on data obtained through dendroclimatological methods, as well as a strong climate signal in a well-reconstructed chronology. Nevertheless, this is a habitual process in climatology that only requires data of temperature and precipitation so that it is possible to calculate trends of climatic variability by means of available specialized software [59].

Dendroclimatology as a proxy tool for past climatic data has gained relevance during the last 12 years, which we observed in the number of published papers. It is probably because of the scrutiny in analyzing the effects of climate change and the need to rely on climatic data of higher and longer temporal resolution [60,61]. We also recognize a lack in Latin America of available dendroclimatology and climate change research until a decade ago [5,62,63]. In that respect, Mexico showed a different trend given that such an increment in published papers did not occur until 2013 [7].

The formation of collaborative research teams developing dendroclimatological research has also favored an increment in publications on this topic. There are mainly three groups of coordinated scholars: one formed by researchers from the United States of America working with Latin American colleagues, a second group including Mexican researchers [7], and a third one including scholars from South America, mainly from Argentina, Chile and Brazil [4,5]. This cohesion has favored the establishment of interhemispheric dendrochronological networks supported by research foundations, such as the one funded by the Inter-American Institute for Global Change Research (IAI), which allows the advancement in the generation of dendrochronological series in the 
American continent [17]. These dendrochronological networks enable more robust future analyses, in topics like the expression of climate signal, the influence of general atmospheric circulation phenomena, the effect of global warming and its observation through dendrochronological techniques, as well as the higher involvement of tree species from tropical and subtropical environments.

A high percentage $(57.4 \%)$ of papers were published by international publishers, perhaps because of the degree of impact and international reach of these journals. The trend, however, is to publish in journals from national research centers, maybe because of the degree of specialization of the research or because of its local and regional relevance. The development of dendroclimatological research in Latin America has been promoted by the training of researchers in recognized tree-ring laboratories and by international collaborations.

The surface of the studied area sampled is infrequently mentioned in papers about dendroclimatology, even though it could delimit the area of influence of climatic variables. We found only three papers providing such information as supplementary data within sections devoted to describing the study area $[35,64,65]$ and giving little importance to it because the potential extension of forest cover is considered the limit of climatic influence [34,66].

Sites suitable for research are required to have certain characteristics for gathering data, such as slope, aspect, and land cover [67-69]. The areas fulfilling these requirements are in zones of altitudinal transition caused by the climatic variation present in them [70]. Consequently, dendroclimatic research can be observed at the local and regional scales because of the advantages and disadvantages implied in the extension of the study areas and the spatial distribution of the species to be analyzed. At both scales, however, the objective is to observe the effects of climate variability on forest mass growth $[4,7,17]$. In Latin America, regional studies are more frequently proposed than local studies, which in some cases could impede defining the study area or the area of influence of the observed parameters, given that local studies mainly focus on analyses belonging to different subdisciplines of dendrochronology.

Another advantage of dendroclimatology is to offer an updated perspective of the degree of anthropogenic impact, which is made through the evaluation of the increment in the cell structures of growth rings. Their cells store chemical components to which terrestrial ecosystems are continuously exposed $[5,13,17]$. It is still possible to make contributions, above all in the fields of wood anatomy and the identification of the cell structures, as well as the influence of climate warming, particularly in broadleaf woody species $[9,26,47,71,72]$.

Publications about the reconstruction of past climates refer to general atmospheric circulation models like the El Niño-Southern Oscillation (ENSO), the Pacific Decadal Oscillation (PDO), the Atlantic Multidecadal Oscillation (AMO), the North American Monsoon System (NAMS), as well as to other similar regional phenomena in South America, because these atmospheric phenomena have been shown to correlate with the of the annual radial growth of trees [8,11,58,73-78]. The need for climatological information has grown in the last few years, given that the analysis and modeling of 
atmospheric dynamics require temporally precise climatological data to propose strategies for facing extreme hydroclimatological events $[32,79,80]$. The potential of growth rings as an archive of climatic variability has been widely discussed, with several published papers containing references to the capacity for dating climate variations with the added advantage of growth rings responding to annual and, in some cases, seasonal variations [4]. Therefore, one of the main trends of dendroclimatological studies is to reconstruct climatic variability and to compile useful databases to generate climatic and hydrological information in sites lacking instrumental data $[5,43,48]$.

The search for tree species offering advantages for the observation of climatic variability has been one of the main dendroclimatological activities over the last years in Latin America. Our finding indicates that almost half of the research has been done using coniferous species and broadleaf species. Through the search for suitable tree species, it has been possible to explore previously unstudied geographic areas and research niches, which enable us to broaden the scope of the methods applied in dendroclimatology [10,29,38,44,48,50,51,81,82]. Argentina, Chile, Mexico and Brazil are the countries where a greater effort has been spent into analyzing the dendrochronological potential of new species, mainly from the genera Pinus, Juniperus, Autrocedrus, Prosopis, Nothofagus, and Pseudotsuga. In addition, Cedrela, Hymenea, Macrolobium, Poincianella, Schinopsis and Piranhea have been studied in Brazil, where these tropical and subtropical species have been used for climatic reconstruction [12,52,83-85] (Figure 7). 

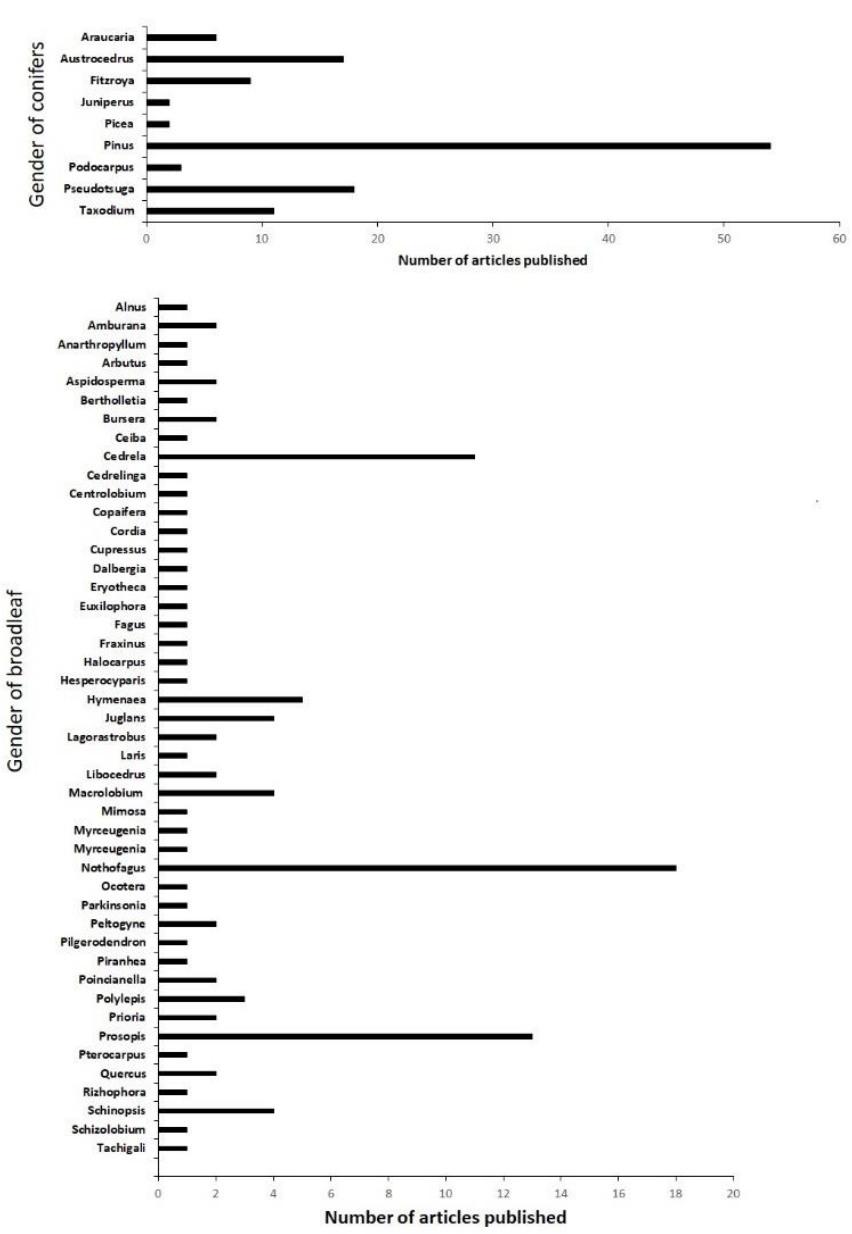

Figure 7. Most used genera in dendroclimatological research in Latin America.

The more used methods for the studies of paleoclimate are based on the physical and chemical properties of the samples to be analyzed, and these could be applied in parallel with dendroclimatology. Lichenometry, ice cores, stratigraphy, and carbon-14 analyses are other methods of chronological dating; however, the temporal resolution of such methods is broad, that may result in dating errors varies between 10 and 100 years [86]. Therefore, dendroclimatology can be used as the most important foundation for the paleoclimatic analysis of the Holocene period because of its relevance being manifest in expressing climatic variability in annual terms for time intervals of several centuries [87-91]. When comparing dendrochronological techniques with other dating methods, it is possible to highlight the resolution offered by growth rings. Consequently, there is a capacity to compare atmospheric climate variability patterns between chronologies obtained in Latin America and other regions of the world [5,92].

\section{Conclusions}

Dendroclimatological studies in Latin America have been mainly developed in temperate climate zones and a lower percentage in tropical or subtropical areas, although, some chronologies have been developed using broadleaf tree species. The forest tree genera studied in Latin America are reliable for dating. The tropical genera 
forming annual growth rings have cellular structures with complex anatomy, making it difficult to develop exactly dated tree-ring series. Nevertheless, these complex structures could represent an advantage in analyzing more detailed variables other than precipitation and temperature because these species may give more information about the impact these variables have on the physiological processes of tree growth. Such an advantage could imply a complex, albeit promising, future for dendroclimatic studies of tropical tree species. We call to increase dendroclimatological research based on subtropical and tropical tree genus poorly studied until today, such as Macrolobium, Hymenaea, Podocarpus or Juglans in southern Mexico and Central America, as well as conifer trees or Polylepis and Juniperus scrubs on low latitude high mountains, such as in Bolivia, Peru, Venezuela, and Colombia. Finally, we invite researchers involved in other areas of knowledge to consider in their work the information generated by dendroclimatology, which currently plays a promising role in the analysis of local and regional climatic processes. The generated dendroclimatic information allows for a better understanding of the spatial and temporal dynamics of climate variability and, consequently, about its effects on landscapes and society. This review allowed us to have an updated and broad view about the dendroclimatic studies in Latin America, identifying currently and frequently studied species, as well as geographic less studied areas, that require to increase dendroclimatic research efforts.

\section{Patents}

Author Contributions: Conceptualization, M.E.M.; methodology, M.E.M and O.D.S.; software, O.D.S.; validation, M.E.M, T.C.A. and J.V.D.; formal analysis, O.D.S.; investigation, M.E.M and O.D.S.; writing - original draft preparation, M.E.M, O.D.S. T.C.A. J.V.D.; writing-review and editing, M.E.M, T.C.A. J.V.D..; All authors have read and agreed to the published version of the manuscript.

Funding: This research was funded by CONACyT - 179386, DGAPA-PAPIT, UNAM - IN107016, and CONACyT - SENER - 246911. O.D.S thanks CONACyT for his doctoral scholarship to obtain a $\mathrm{PhD}$ degree in Geography in UNAM. M.E.M. thanks PASPA-UNAM for his sabbatical grant.

Institutional Review Board Statement: Not applicable.

Informed Consent Statement: Not applicable.

Acknowledgments: O.D.S thanks CONACyT for his doctoral scholarship to obtain a PhD degree in Geography in UNAM. M.E.M. thanks PASPA-UNAM for his sabbatical grant. Finally, we thank Dr. Sergio Zárate and Mary-Ann Hall for their professional support in revising the English version of the manuscript. We deeply appreciate Dr. Olav Slaymaker for their valuable comments for improving this manuscript.

Conflicts of Interest: The authors declare no conflict of interest. The funders had no role in the design of the study; in the collection, analyses, or interpretation of data; in the writing of the manuscript, or in the decision to publish the results.

\section{References}

1. Douglass, A.E. Climatic Cycles and Tree-Growth: A Study of the Annual Rings of Trees in Relation to Climate and Solar Activity. J. Ecol. 1920, 8, 62-63, doi:10.2307/2255215. 
2. Fritts, H.C. Tree Rings and Climate; Academic Press: London-New York-San Francisco, USA, 1976; pp. 567. ISBN 978-1-930665-39-2.

3. del Rosario Prieto, M.; Solari, M.E.; Crouchet, J.; Larroucau, A. Documentary sources to study the climate in the far south region of Chile $\left(40^{\circ}-51^{\circ} \mathrm{S}\right)$ during the last centuries. Bosque 2012, 33, 135-144, doi:10.4067/S0717-92002012000200003.

4. Hughes, M.K. Dendrochronology in climatology - The state of the art. Dendrochronologia 2002, 20, 95-116, doi:10.1078/1125-7865-00011.

5. Boninsegna, J.A.; Argollo, J.; Aravena, J.C.; Barichivich, J.; Christie, D.; Ferrero, M.E.; Lara, A.; Le Quesne, C.; Luckman, B.H.; Masiokas, M.; et al. Dendroclimatological reconstructions in South America: A review. Palaeogeogr. Palaeoclimatol. Palaeoecol. 2009, 281, 210-228, doi:10.1016/j.palaeo.2009.07.020.

6. Speer, J.H. Fundamentals of tree-ring research; University of Arizona Press; Tucson, USA, 2010; pp.333. ISBN 978-0-8165-2684-0.

7. Acosta-Hernández, A.C.; Pompa-García, M.; Camarero, J.J. An updated review of dendrochronological investigations in Mexico, a megadiverse country with a high potential for tree-ring sciences. Forests 2017, 8, 160, doi:10.3390/f8050160.

8. Fortes, C.F.; Nunes-da-Cunha, C.; Rosa, S.A.; Paixão, E.; Junk, W.J.; Schöngart, J. Dendrochronological records of a pioneer tree species containing ENSO signal in the Pantanal, Brazil. Rev. Bras. Bot. 2018, 41, 167-174, doi:10.1007/s40415-017-0434-8.

9. Granato-Souza, D.; Adenesky-Filho, E.; Esemann-Quadros, K. Dendrochronology and climatic signals in the wood of Nectandra oppositifolia from a dense rain forest in southern Brazil. J. For. Res. 2019, 30, 545-553, doi:10.1007/s11676-018-0687-5.

10. Layme-Huaman, E.T.; Ferrero, M.E.; Palacios-Lazaro, K.S.; Requena-Rojas, E.J. Cedrela nebulosa: A novel species for dendroclimatological studies in the montane tropics of South America. Dendrochronologia 2018, 50, 105-112, doi:10.1016/j.dendro.2018.06.004.

11. Lopez, L.; Stahle, D.; Villalba, R.; Torbenson, M.; Feng, S.; Cook, E. Tree ring reconstructed rainfall over the southern Amazon Basin. Geophys. Res. Lett. 2017, 44, 7410-7418, doi:10.1002/2017GL073363.

12. López, L.; Villalba, R. An assessment of Schinopsis brasiliensis Engler (Anacardiacea) for dendroclimatological applications in the tropical Cerrado and Chaco forests, Bolivia. Dendrochronologia 2016, 40, 85-92, doi:10.1016/j.dendro.2016.07.002.

13. Vasconcellos, T.J. de; Tomazello-Filho, M.; Callado, C.H. Dendrochronology and dendroclimatology of Ceiba speciosa (A. St.-Hil.) Ravenna (Malvaceae) exposed to urban pollution in Rio de Janeiro city, Brazil. Dendrochronologia 2019, 53, 104-113, doi:10.1016/j.dendro.2018.12.004.

14. Villanueva-Díaz, J.; Stahle, D.W.; Cleaveland, M.K.; Therrell, M.D. Estado actual de la dendrocronología en México. Rev. Cienc. For. en México 2003, 25, 5-36.

15. de Miranda, D.L.C.; Higuchi, N.; Trumbore, S.E.; Latorraca, J.V.F.; do Carmo, J.F.; Lima, A.J.N. Using radiocarbon-calibrated dendrochronology to improve tree-cutting cycle estimates for timber management in southern Amazon forests. Trees - Struct. Funct. 2018, 32, 587-602, doi:10.1007/s00468-018-1658-3.

16. Hess, A.F.; Ricken, P.; Ciarnoschi, L.D. Dendrochronology, increment and forest management in Araucaria forest, Santa Catarina state. Cienc. Florest. 2018, 28, 1568-1582, doi:10.5902/1980509835104.

17. Luckman, B.H. Dendrochronology and Human Dimensions Issues in Global Change. Dendrochronologia 2005, 22, 131-134, doi:10.1016/j.dendro.2005.05.001.

18. Wang, H.; Pardo-Igúzquiza, E.; Dowd, P.A.; Yang, Y. Comparison of statistical methods for testing the hypothesis of constant global mean in spatial statistics. Spat. Stat. 2018, 23, 143-169, doi:10.1016/j.spasta.2018.01.001.

19. Amoroso, M.M.; Daniels, L.D.; Larson, B.C. Temporal patterns of radial growth in declining Austrocedrus chilensis forests in Northern Patagonia: The use of tree-rings as an indicator of forest decline. For. Ecol. Manage. 2012, 265, 62-70, doi:10.1016/j.foreco.2011.10.021.

20. Masiokas, M.H.; Villalba, R.; Christie, D.A.; Betman, E.; Luckman, B.H.; Le Quesne, C.; Prieto, M.R.; Mauget, S. Snowpack variations since $\mathrm{AD} 1150$ in the Andes of Chile and Argentina $\left(30^{\circ}-37^{\circ} \mathrm{S}\right)$ inferred from rainfall, tree-ring and documentary records. J. Geophys. Res. Atmos. 2012, 117, D05112, doi:10.1029/2011JD016748. 
21. Villalba, R.; Veblen, T.T. Regional patterns of tree population age structures in Northern Patagonia: climatic and disturbance influences. J. Ecol. 1997, 85, 113-124, doi:10.2307/2960643.

22. Decuyper, M.; Chávez, R.O.; Copini, P.; Sass-Klaassen, U. A multi-scale approach to assess the effect of groundwater extraction on Prosopis tamarugo in the Atacama Desert. J. Arid Environ. 2016, 131, 25-34, doi:10.1016/j.jaridenv.2016.03.014.

23. Ferrero, M.E.; Villalba, R. Potential of Schinopsis lorentzii for dendrochronological studies in subtropical dry Chaco forests of South America. Trees - Struct. Funct. 2009, 23, 167-174, doi:10.1007/s00468-009-0369-1.

24. Inga, J.G.; del Valle, J.I. Log-relative growth: A new dendrochronological approach to study diameter growth in Cedrela odorata and Juglans neotropica, Central Forest, Peru. Dendrochronologia 2017, 44, 117-129, doi:10.1016/j.dendro.2017.03.009.

25. Cerano, J.P.; Villanueva, J.D.; Cervantes, R.M.; Vázquez, L.S.; Trucios, R.C.; Guerra, V.D.L.C. Reconstrucción de precipitación invierno-primavera para el Parque Nacional Pico de Tancítaro, Michoacán. Investig. Geogr. 2014, 83, 41-54, doi:10.14350/rig.35190.

26. Pompa-García, M.; González-Cásares, M.; Acosta-Hernández, A.C.; Camarero, J.J.; Rodríguez-Catón, M. Drought influence over radial growth of Mexican conifers inhabiting mesic and xeric sites. Forests 2017, 8, 175, doi:10.3390/f8050175.

27. Villanueva Díaz, J.; Cerano Paredes, J.; Vázquez Selem, L.; Stahle W., D.; Z. Fulé, P.; L. Yocom, L.; Franco Ramos, O.; Ruiz Corral, J.A. Red dendrocronológica del pino de altura (Pinus hartwegii Lindl.) para estudios dendroclimáticos en el noreste y centro de México. Investig. Geogr. 2015, 86, 5-14.

28. Le Quesne, C.; Acuña, C.; Boninsegna, J.A.; Rivera, A.; Barichivich, J. Long-term glacier variations in the Central Andes of Argentina and Chile, inferred from historical records and tree-ring reconstructed precipitation. Palaeogeogr. Palaeoclimatol. Palaeoecol. 2009, 281, 334-344, doi:10.1016/j.palaeo.2008.01.039.

29. Rozas, V.; Le Quesne, C.; Rojas-Badilla, M. Factores climáticos que controlan el crecimiento radial y la formación de fluctuaciones de densidad en la madera de Austrocedrus chilensis en Valdivia, Chile. Bosque 2016, 37, 461-471, doi:10.4067/S0717-92002016000300003.

30. Cleaveland, M.K.; Stahle, D.W.; Therrell, M.D.; Villanueva-Diaz, J.; Burns, B.T. Tree-ring reconstructed winter precipitation and tropical teleconnections in Durango, Mexico. Clim. Change 2003, 59, 369-388, doi:10.1023/A:1024835630188.

31. Cortés, B.; Nayeli, E.; Villanueva Díaz, J.; Nieto de Pascual Pola, C.; Estrada Ávalos, J.; Guerra de la Cruz, V. Reconstrucción de precipitación estacional para el noroeste de Guanajuato. Rev. Mex. ciencias For. 2012, 3, 51-67.

32. Villanueva Díaz, J.; Cerano Paredes, J.; Constante García, V.; Stahle, D.; Estrada Ávalos, J.; Tostado Plascencia, M. Variabilidad hidroclimática histórica del norte de México inferida con anillos de crecimiento de Douglas-fir. Rev. Mex. ciencias agrícolas 2011, 2, 221-334.

33. Villanueva-Diaz, J.; Luckman, B.H.; Stahle, D.W.; Therrell, M.D.; Cleaveland, M.K.; Cerano-Paredes, J.; Gutierrez-Garcia, G.; Estrada-Avalos, J.; Jasso-Ibarra, R. Hydroclimatic variability of the upper Nazas basin: Water management implications for the irrigated area of the Comarca Lagunera, Mexico. Dendrochronologia 2005, 22, 215-223, doi:10.1016/j.dendro.2005.04.005.

34. Villanueva-Diaz, J.; Stahle, D.W.; Luckman, B.H.; Cerano-Paredes, J.; Therrell, M.D.; Cleaveland, M.K.; Cornejo-Oviedo, E. Winter-spring precipitation reconstructions from tree rings for northeast Mexico. Clim. Change 2007, 83, 117-131, doi:10.1007/s10584-006-9144-0.

35. Anchukaitis, K.J.; Evans, M.N.; Wheelwright, N.T.; Schra, D.P. Stable isotope chronology and climate signal calibration in neotropical montane cloud forest trees. J. Geophys. Res. Biogeosciences 2008, 113, G03030, doi:10.1029/2007JG000613.

36. Beramendi-Orosco, L.; Gonzalez-Hernandez, G.; Martinez-Jurado, A.; Martinez-Reyes, A.; Garcia-Samano, A.; Villanueva-Diaz, J.; Javier Santos-Arevalo, F.; Gomez-Martinez, I.; Amador-Muñoz, O. Temporal and Spatial Variations of Atmospheric Radiocarbon in the Mexico City Metropolitan Area. Radiocarbon 2015, 57, 363-375, doi:10.2458/azu_rc.57.18360.

37. Mundo, I.A.; Juñent, F.A.R.; Villalba, R.; Kitzberger, T.; Barrera, M.D. Araucaria araucana tree-ring chronologies in Argentina: Spatial growth variations and climate influences. Trees - Struct. Funct. 2012, 26, 443-458, doi:10.1007/s00468-011-0605-3.

38. Amoroso, M.M.; Daniels, L.D.; Villalba, R.; Cherubini, P. Does drought incite tree decline and death in Austrocedrus chilensis 
forests? J. Veg. Sci. 2015, 26, 1171-1183, doi:10.1111/jvs.12320.

39. Cervantes-Martínez, R.; Cerano-Paredes, J.; Sánchez-Martínez, G.; Villanueva-Díaz, J.; Esquivel-Arriaga, G.; Cambrón-Sandoval, V.H.; Méndez-González, J.; Castruita-Esparza, L.U. Historical bark beetle outbreaks in Mexico, Guatemala and Honduras (1985-2015) and their relationship with droughts. Rev. Chapingo Ser. Ciencias For. y del Ambient. 2019, 25, 269-290, doi:10.5154/r.rchscfa.2019.01.006.

40. Mundo, I.A.; El Mujtar, V.A.; Perdomo, M.H.; Gallo, L.A.; Villalba, R.; Barrera, M.D. Austrocedrus chilensis growth decline in relation to drought events in northern Patagonia, Argentina. Trees - Struct. Funct. 2010, 24, 561-570, doi:10.1007/s00468-010-0427-8.

41. Cortés Montaño, C.; Fulé, P.Z.; Falk, D.A.; Villanueva-Díaz, J.; Yocom, L.L. Linking old-growth forest composition, structure, fire history, climate and land-use in the mountains of northern México. Ecosphere 2012, 3, 1-16, doi:10.1890/es12-00161.1.

42. Fulé, P.Z.; Villanueva-Díaz, J.; Ramos-Gómez, M. Fire regime in a conservation reserve in Chihuahua, Mexico. Can. J. For. Res. 2005, 35, 320-330, doi:10.1139/x04-173.

43. Roig, F.A.; Osornio, J.J.J.; Diaz, J.V.; Luckman, B.; Tiessen, H.; Medina, A.; Noellemeyer, E.J. Anatomy of growth rings at the Yucatán Peninsula. Dendrochronologia 2005, 22, 187-193, doi:10.1016/j.dendro.2005.05.007.

44. Worbes, M.; Raschke, N. Carbon allocation in a Costa Rican dry forest derived from tree ring analysis. Dendrochronologia 2012, 30, 231-238, doi:10.1016/j.dendro.2011.11.001.

45. Biondi, F.; Hartsough, P.C.; Estrada, I.G. Daily weather and tree growth at the tropical treeline of North America. Arctic, Antarct. Alp. Res. 2005, 37, 16-24, doi:10.1657/1523-0430(2005)037[0016:DWATGA]2.0.CO;2.

46. Brienen, R.J.W.; Zuidema, P.A. Relating tree growth to rainfall in Bolivian rain forests: A test for six species using tree ring analysis. Oecologia 2005, 146, 1-12, doi:10.1007/s00442-005-0160-y.

47. Carlón-Allende, T.; Villanueva-Díaz, J.; Mendoza, M.E.; Pérez-Salicrup, D.R. Climatic signal in earlywood and latewood in conifer forests in the monarch butterfly biosphere reserve, Mexico. Tree-Ring Res. 2018, 74, 63-75, doi:10.3959/1536-1098-74.1.63.

48. Carlón Allende, T.; Mendoza, M.E.; Villanueva Díaz, J.; Li, Y. Climatic response of Pinus cembroides Zucc. radial growth in Sierra del Cubo, Guanajuato, Mexico. Trees - Struct. Funct. 2018, 32, 1387-1399, doi:10.1007/s00468-018-1720-1.

49. Carlón Allende, T.; Mendoza, M.E.; Pérez-Salicrup, D.R.; Villanueva-Díaz, J.; Lara, A. Climatic responses of Pinus pseudostrobus and Abies religiosa in the Monarch Butterfly Biosphere Reserve, Central Mexico. Dendrochronologia 2016, 38, 103-116, doi:10.1016/j.dendro.2016.04.002.

50. Rozas, V.; Le Quesne, C.; Muñoz, A.; Puchi, P. Climate and growth of Podocarpus salignus in Valdivia, Chile. Dendrobiology 2016, 76, 3-11, doi:10.12657/denbio.076.001.

51. Peña, M.P.; Barichivich, J.; Maldonado, A. Climatic drivers of tree growth in a swamp forest island in the semiarid coast of Chile. J. Arid Environ. 2014, 109, 15-22, doi:10.1016/j.jaridenv.2014.05.003.

52. Batista, E.S.; Schöngart, J. Dendroecology of Macrolobium acaciifolium (Fabaceae) in central Amazonian floodplain forests. Acta Amaz. 2018, 48, 311-320, doi:10.1590/1809-4392201800302.

53. Tomazello Filho, M.; Lisi, C.S.; Hansen, N.; Cury, G. Anatomical features of increment zones in different tree species in the State of São Paulo, Brazil. Sci. For. 2004, 66, 46-55.

54. Schweingruber, F. Trees and Wood in Dendrochronology Morphological, Anatomical, and Tree-Ring Analytical Characteristics of Trees Frequently Used in Dendrochronology; Springer-Verlag, Berlin, Germany,1993; pp. 402. ISBN 9783642771590.

55. Cerano-Paredes, J.; Méndez-González, J.; Amaro-Sánchez, A.; Villanueva-Díaz, J.; Cervantes-Martínez, R.; Rubio-Camacho, E.A. Reconstrucción de precipitación invierno-primavera con anillos anuales de Pinus douglasiana en la reserva de la biosfera sierra de manantlán, Jalisco. Rev. Chapingo, Ser. Ciencias For. y del Ambient. 2013, 19, 413-423,

doi:10.5154/r.rchscfa.2013.02.007.

56. Santillán-Hernández, M.; Cornejo-Oviedo, E.H.; Villanueva-Díaz, J.; Cerano-Paredes, J.; Valencia-Manzo, S.; Capó-Arteaga, 
M.Á. Dendroclimatic potential of Pinus pinceana Gordon in the Sierra Madre Oriental. Madera y Bosques 2010, 16, 17-30, doi:10.21829/myb.2010.1611177.

57. Stahle, D.W.; Cook, E.R.; Burnette, D.J.; Torbenson, M.C.A.; Howard, I.M.; Griffin, D.; Diaz, J.V.; Cook, B.I.; Williams, A.P.; Watson, E.; et al. Dynamics, Variability, and Change in Seasonal Precipitation Reconstructions for North America. J. Clim. 2020, 33, 3173-3195, doi:10.1175/jcli-d-19-0270.1.

58. Stahle, D.W.; Cook, E.R.; Burnette, D.J.; Villanueva, J.; Cerano, J.; Burns, J.N.; Griffin, D.; Cook, B.I.; Acuña, R.; Torbenson, M.C.A.; et al. The Mexican Drought Atlas: Tree-ring reconstructions of the soil moisture balance during the late pre-Hispanic, colonial, and modern eras. Quat. Sci. Rev. 2016, 149, 34-60, doi:10.1016/j.quascirev.2016.06.018.

59. Zhang, X.; David Harvey, K.; Hogg, W.D.; Yuzyk, T.R. Trends in Canadian streamflow. Water Resour. Res. 2001, 37, 987-998, doi:10.1029/2000WR900357.

60. Lara, A.; Villalba, R.; Urrutia, R. A 400-year tree-ring record of the Puelo River summer-fall streamflow in the Valdivian Rainforest eco-region, Chile. Clim. Change 2008, 86, 331-356, doi:10.1007/s10584-007-9287-7.

61. Le Quesne, C.; Stahle, D.W.; Cleaveland, M.K.; Therrell, M.D.; Aravena, J.C.; Barichivich, J. Ancient Austrocedrus tree-ring chronologies used to reconstruct central Chile precipitation variability from A.D. 1200 to 2000. J. Clim. 2006, 19, 5731-5744, doi:10.1175/JCLI3935.1.

62. Shi, C.; Masson-Delmotte, V.; Daux, V.; Li, Z.; Carré, M.; Moore, J.C. Unprecedented recent warming rate and temperature variability over the east Tibetan Plateau inferred from Alpine treeline dendrochronology. Clim. Dyn. 2015, 45, 1367-1380, doi:10.1007/s00382-014-2386-z.

63. Takahashi, K.; Okuhara, I. Forecasting the effects of global warming on radial growth of subalpine trees at the upper and lower distribution limits in central Japan. Clim. Change 2013, 117, 273-287, doi:10.1007/s10584-012-0547-9.

64. Costa, M.S.; Ferreira, K.E.B.; Botosso, P.C.; Callado, C.H. Growth analysis of five Leguminosae native tree species from a seasonal semidecidual lowland forest in Brazil. Dendrochronologia 2015, 36, 23-32, doi:10.1016/j.dendro.2015.08.004.

65. Watmough, S.A.; Hutchinson, T.C. Change in the dendrochemistry of sacred fir close to Mexico City over the past 100 years. Environ. Pollut. 1999, 104, 79-88, doi:10.1016/S0269-7491(98)00150-X.

66. Lara, A.; Villalba, R.; Wolodarsky-Franke, A.; Aravena, J.C.; Luckman, B.H.; Cuq, E. Spatial and temporal variation in Nothofagus pumilio growth at tree line along its latitudinal range $\left(35^{\circ} 40^{\prime}-55^{\circ} \mathrm{S}\right)$ in the Chilean Andes. J. Biogeogr. 2005, 32, 879-893, doi:10.1111/j.1365-2699.2005.01191.x.

67. Carlón-Allende, T.; Mendoza, M.E.; Villanueva-Díaz, J.; Pérez-Salicrup, D.R. Análisis espacial del paisaje como base para muestreos dendrocronológicos: El caso de la reserva de la biosfera Mariposa Monarca, México. Madera y Bosques 2015, 21, 11-22, doi:10.21829/myb.2015.212442.

68. Hairston, A.B.; Grigal, D.F. Topographic influences on soils and trees within single mapping units on a sandy outwash landscape. For. Ecol. Manage. 1991, 43, 35-45, doi:10.1016/0378-1127(91)90074-6.

69. Mäkinen, H.; Nöjd, P.; Kahle, H.P.; Neumann, U.; Tveite, B.; Mielikäinen, K.; Röhle, H.; Spiecker, H. Radial growth variation of Norway spruce (Picea abies (L.) Karst.) across latitudinal and altitudinal gradients in central and northern Europe. For. Ecol. Manage. 2002, 171, 243-259, doi:10.1016/S0378-1127(01)00786-1.

70. Dittmar, C.; Zech, W.; Elling, W. Growth variations of Common beech (Fagus sylvatica L.) under different climatic and environmental conditions in Europe - A dendroecological study. For. Ecol. Manage. 2003, 173, 63-78, doi:10.1016/S0378-1127(01)00816-7.

71. González-Elizondo, M.; Jurado, E.; Návar, J.; González-Elizondo, M.S.; Villanueva, J.; Aguirre, O.; Jiménez, J. Tree-rings and climate relationships for Douglas-fir chronologies from the Sierra Madre Occidental, Mexico: A 1681-2001 rain reconstruction. For. Ecol. Manage. 2005, 213, 39-53, doi:10.1016/j.foreco.2005.03.012.

72. Villalba, R.; Grosjean, M.; Kiefer, T. Long-term multi-proxy climate reconstructions and dynamics in South America (LOTRED-SA): State of the art and perspectives. Palaeogeogr. Palaeoclimatol. Palaeoecol. 2009, 281, 175-179, 
doi:10.1016/j.palaeo.2009.08.007.

73. Ortlieb, L.; Macharé, J. Former El Niño events: records from western South America. Glob. Planet. Change 1993, 7, 181-202, doi:10.1016/0921-8181(93)90049-T.

74. Poveda, G.; Waylen, P.R.; Pulwarty, R.S. Annual and inter-annual variability of the present climate in northern South America and southern Mesoamerica. Palaeogeogr. Palaeoclimatol. Palaeoecol. 2006, 234, 3-27, doi:10.1016/j.palaeo.2005.10.031.

75. Rodríguez, R.; Mabres, A.; Luckman, B.; Evans, M.; Masiokas, M.; Ektvedt, T.M. “El Niño” events recorded in dry-forest species of the lowlands of northwest Peru. Dendrochronologia 2005, 22, 181-186, doi:10.1016/j.dendro.2005.05.002.

76. Stahle, D.W.; Burnette, D.J.; Diaz, J.V.; Heim, R.R.; Fye, F.K.; Paredes, J.C.; Soto, R.A.; Cleaveland, M.K. Pacific and Atlantic influences on Mesoamerican climate over the past millennium. Clim. Dyn. 2012, 39, 1431-1446, doi:10.1007/s00382-011-1205-z.

77. Stahle, D.W.; Diaz, J.V.; Burnette, D.J.; Paredes, J.C.; Heim, R.R.; Fye, F.K.; Acuna Soto, R.; Therrell, M.D.; Cleaveland, M.K.; Stahle, D.K. Major Mesoamerican droughts of the past millennium. Geophys. Res. Lett. 2011, 38, L05703, doi:10.1029/2010GL046472.

78. Villanueva-Díaz, J.; González-Elizondo, M.; Cerano-Paredes, J.; Ávalos, J.E.; Sifuentes, A.R.M.; Mata, S.R. Dendrochronological potential of sad pine (Pinus lumholtzii B.L. Rob. \& Fernald) in the sierra madre occidental for seasonal rainfall reconstructions. Madera y Bosques 2018, 24, 1-31, doi:10.21829/myb.2018.2421530.

79. Cook, B.I.; Cook, E.R.; Smerdon, J.E.; Seager, R.; Williams, A.P.; Coats, S.; Stahle, D.W.; Díaz, J.V. North American megadroughts in the Common Era: Reconstructions and simulations. Wiley Interdiscip. Rev. Clim. Chang. 2016, 7, 411-432, doi:10.1002/wcc.394.

80. Endfield, G.H.; Tejedo, I.F. Decades of drought, years of hunger: Archival investigations of multiple year droughts in late colonial Chihuahua. Clim. Change 2006, 75, 391-419, doi:10.1007/s10584-006-3492-7.

81. Barichivich, J.; Sauchyn, D.J.; Lara, A. Climate signals in high elevation tree-rings from the semiarid Andes of north-central Chile: Responses to regional and large-scale variability. Palaeogeogr. Palaeoclimatol. Palaeoecol. 2009, 281, 320-333, doi:10.1016/j.palaeo.2007.10.033.

82. Villanueva-Díaz, J.; Rubio-Camacho, E.A.; Chávez-Durán, Á.A.; Zavala-Aguirre, J.L.; Cerano-Paredes, J.; Martínez-Sifuentes, A.R. Climatic response of Pinus oocarpa schiede Ex Schetol in the “La Primavera” forest, Jalisco. Madera y Bosques 2018, 24, 1-31, doi:10.21829/myb.2018.2411464.

83. Locosselli, G.M.; Cardim, R.H.; Ceccantini, G. Rock outcrops reduce temperature-induced stress for tropical conifer by decoupling regional climate in the semiarid environment. Int. J. Biometeorol. 2016, 60, 639-649, doi:10.1007/s00484-015-1058-y.

84. Pagotto, M.A.; Roig, F.A.; de Souza Ribeiro, A.; Lisi, C.S. Influence of regional rainfall and Atlantic sea surface temperature on tree-ring growth of Poincianella pyramidalis, semiarid forest from Brazil. Dendrochronologia 2015, 35, 14-23, doi:10.1016/j.dendro.2015.05.007.

85. Schöngart, J.; Junk, W.J.; Piedade, M.T.F.; Ayres, J.M.; Hüttermann, A.; Worbes, M. Teleconnection between tree growth in the Amazonian floodplains and the El Niño-Southern Oscillation effect. Glob. Chang. Biol. 2004, 10, 683-692, doi:10.1111/j.1529-8817.2003.00754.x.

86. Noller, J.S., Sowers, J.M., Lettis, W.R. Quaternary Geochronology: Methods and Applications; American Geophysical Union Reference Shelf 4, Washington, D.C, USA, 2000; pp. 584. ISBN 0-87590-950-7.

87. Alcalá-Reygosa, J.; Palacios, D.; Schimmelpfennig, I.; Vázquez-Selem, L.; García-Sancho, L.; Franco-Ramos, O.; Villanueva, J.; Zamorano, J.J.; Aumaître, G.; Bourlès, D.; et al. Dating late Holocene lava flows in Pico de Orizaba (Mexico) by means of in situ-produced cosmogenic 36Cl, lichenometry and dendrochronology. Quat. Geochronol. 2018, 47, 93-106, doi:10.1016/j.quageo.2018.05.011.

88. Beramendi-Orosco, L.E.; González-Hernández, G.; Martínez-Reyes, A.; Morton-Bermea, O.; Santos-Arévalo, F.J.; Gómez-Martínez, I.; Villanueva-Díaz, J. Changes in CO2 emission sources in Mexico city metropolitan area deduced from 
radiocarbon concentrations in tree rings. Radiocarbon 2018, 60, 21-34, doi:10.1017/RDC.2017.100.

89. Beramendi-Orosco, L.E.; Gonzalez-Hernandez, G.; Villanueva-Diaz, J.; Santos-Arevalo, F.J.; Gómez-Martinez, I.; Cienfuegos-Alvarado, E.; Morales-Puente, P.; Urrutia-Fucugauchi, J. Modern radiocarbon levels for northwestern mexico derived from tree rings: A comparison with northern hemisphere zones 2 and 3 curves. Radiocarbon 2010, 52, 907-914, doi:10.1017/S0033822200046002.

90. Bradley, R.S. Paleoclimatology: Reconstructing Climates of the Quaternary; Elsevier Academic Press, International Geophysics Series. California, USA, 1999; pp. 595; ISBN 978-0-12-386913-5.

91. Cronin, T.M. Principles of paleoclimatology; Columbia University Press: New York, USA, 1999; pp. 560, ISBN 0231109547.

92. Szeicz, J.M.; Haberle, S.G.; Bennett, K.D. Dynamics of North Patagonian rainforests from fine-resolution pollen, charcoal and tree-ring analysis, Chonos Archipelago, Southern Chile. Austral Ecol. 2003, 28, 413-422, doi:10.1046/j.1442-9993.2003.01299.x. 